\title{
Influence of Motivation, Discipline and Professionalism on Teacher Performance in Junior High School in Air Kumbang District
}

\author{
Mgs. Muhammad $\mathrm{Ali}^{1 *}$, Happy Fitria ${ }^{2}$, Achmad Wahidy ${ }^{2}$ \\ ${ }^{1}$ Dinas Pendidikan dan Kebudayaan Kabupaten Banyuasin, South of Sumatera, Indonesia \\ ${ }^{2}$ Universitas PGRI Palembang, Indonesia \\ *Corresponding author. Email: alimmasagus@gmail.com
}

\begin{abstract}
The aim of this study was to learn about and describe the impact of motivation, discipline, and professionalism on teacher performance at junior high schools in Air Kumbang District, Banyuasin Regency. This study's population consisted of all junior high school teachers from 7 (seven) junior high schools in the Air Kumbang District, for a total of 119 teachers. The descriptive quantitative approach was employed in this analysis. The findings of this study indicate that: (1) motivation has a significant influence on teacher performance; (2) discipline has a significant influence on teacher performance; (3) professionalism has a significant influence on teacher performance; and (4) motivation and discipline have a significant influence on teacher performance.
\end{abstract}

Keywords: Motivation, Discipline, Professionalism, Teacher Performance

\section{INTRODUCTION}

National advancement of education is an attempt to educate the nation's life and increase the quality of faithful human beings, devout and noble and master the science of technology and art in realizing an advanced, just, prosperous and civilized society. Law Number 20 of 2003 concerning the National Education System, stated: "Education is a conscious and systematic effort carried out by planning to create an atmosphere of a learning climate and a learning process for students to explore their potential so that they have religious spiritual strength, are able to manage emotions as a form of self-control, have a good personality, have intelligence, have a noble character, as well as other competencies or skills needed by himself, society, the nation and the State ". The matters mandated by the law can be achieved through education. A good education will give good results. To carry out education is in the Teacher, the role of the teacher is very large in the world of education, because the true task of the teacher is to provide the knowledge that is owned according to the field of knowledge to all students, not only that the teacher also educates, provides examples and guides students to become knowledgeable and character with good character provision of life for their students. If you want to get optimal results, an educational institution really needs teachers who are capable, skilled and have good performance. Since one of the deciding factors in improving educational quality is in the hands of the teacher. Teachers play an equally important role in achieving educational achievement as schools do, since teachers are an essential component of the educational system. Without the support of teachers who are professional, disciplined, have good motivation and performance, it will not produce good quality education.

In achieving the goals of National Education, teachers play an important role in deciding the quality of their students, and one of the strategic factors in determining the degree of achievement is the role and function of teachers. Teachers are the most significant aspect of the teaching and learning processes of both formal and informal education. Consequently, motivation, discipline, professionalism and teacher performance are indispensable in shaping the character of future teachers who are reliable and professional.

Motivation according to Robbins and Judge [1] is a process of intensity, direction and persistence in achieving goals. Samsudin [2] defines motivation as an external process that encourages and influences a person or work community to want to do something that is determined. Motivation can also be interpreted as a natural driving force for satisfaction and survival. According to Uno [3] the occurrence of motivation when a person has a desire and willingness to carry out 
an activity or action to achieve a goal. Apart from that, there is also an impulse that is caused by stimuli from within or from outside, so that someone has the desire to make certain changes towards a better direction than before.

Anoraga [4] explains that motivation is a need that encourages doing an action towards a certain goal. According to Lian [5] motivation is a desire from the heart to get something. According to Aprida, et al [6] motivation is an encouragement for individuals from within and from outside which affects the quality of work for that individual. Work motivation is something that can lead to an increase in morale. Therefore, the size of the achievement is influenced by the high and low work motivation of a person.

Job discipline, according to Rivai [7], is "a method used by managers to interact with workers in order to improve actions in an attempt to increase one's sensitivity and ability to comply with all company rules and relevant social norms". According to Umami, et al [8], discipline is an act or behavior of a person so that he can always comply with the agreed rules.

Davis [9] states that work discipline is the implementation of management in strengthening a guideline that is closely related to performance. According to Hasibuan [10], discipline is a person's knowledge and ability to follow the rules and social norms that apply throughout the organization. According to Wirawan [11], discipline is the conduct of employees who obey and follow standard operating procedures, code of ethics, standards of behavior and work regulations set by the organization.

Rohani, et al [12] state that discipline in an organization is the level of a work team that is shown by employee self-control in carrying out work tasks regularly. Job discipline is intertwined with employee actions and efficiency. Discipline is a school-wide initiative to ensure that teachers and administrative personnel can follow and enforce relevant regulations. One of the most critical factors in producing innovative and quality human beings is teacher discipline.

Professionalism, according to Ahmad and Hodsay [13], shows the degree of a person's appearance as a professional or the appearance of something in the church with his professional duties, there are low, medium and high professionalism. Professionalism which also refers to a commitment or attitude as a member of a profession to work with high standards and with the professional code of ethics. So that professionalism is a performance quality which is also a demand for professional behavior in carrying out every task. Professionalism is also defined as a person's skills and abilities to do work according to their respective levels and fields.

The concept of performance is simply expressed by Jex and Britt, in Fitria [14], which defines performance as, "job performance is all the behaviors performed by employees while working". This definition confirms that performance is all the behavior of employees who are involved in their work.

Performance described by Ahmad [15], is a term used in various literatures, there are various translations, namely the word job performance and work performance, the word performance can be translated as performance (English), which has several meanings, including (1) action; (2) effectiveness, achievement and results, (3) carrying out obligations or duties. Fattah and Wardarita [16] define performance as an outcome or product of work assigned to someone in an institution / organization. A person's performance relates to aspects of that person's behavior in tasks carried out for the organization according to assigned authority. Performance is not only a result, but also relates to independence, consistent with an organization's values, about understanding an issue related to responsibility, discipline and good communication.

Hapizoh, et al [17] state that professionalism is a certain skill that has certain competences (knowledge, attitudes, and skills) according to its specific and intensive expertise obtained in academic education.

Brury [18] explains that performance is work performance, work result or work performance. The ability to carry out a task or performance (performance) is something that can continuously increase the motivation function. Thus, a teacher's job output in terms of quality and quantity attained when carrying out his duties is consistent with the tasks delegated to him. Meanwhile, Yamin and Maisah [19] state "teacher performance is a behavior or response that gives results that refer to what they do when they face a task". The Directorate of Education Personnel in Barnawi and Arifin [20] explains that the definition of "Success" is described as "a type of action of an individual or organization with an achievement orientation". A form of behavior that is produced by someone from an organization in the form of a result of a job or an achievement produced by someone who is a contribution to the organization. Fitria [14] explains that what is meant by performance in this study is a person's performance at work within a certain period of time. The performance indicators are: work quality, work accuracy, initiative, ability, and communication.

The five aspects above are applications of teacher performance: (1) the standard of job is directly in relation to ability of teachers in mastering all things related to the learning process, which consists of lesson materials, management of teaching and learning and class management; (2) speed or accuracy of work, is an indicator related to the use of instructional media in accordance with the content of learning materials, even directly related to the accuracy of teachers in planning the learning program with the time available; (3) initiative in work, is the ability of teachers in, lead the class, manage the interaction of learning and teaching in the class well and correctly, up to the assessment of 
student learning outcomes; (4) work ability, can be seen from the indicators of teacher's ability include the use of various methods in learning, understanding and implementing functions and guidance counseling services to students who need guidance and direction, and (5) communication in this indicator teachers are expected to speak well, understand and organize school administration, and develop its capabilities.

\section{METHODS}

This thesis employs a descriptive analysis method in conjunction with a quantitative approach. According to
Sugiyono [21], quantitative analysis is used to analyze particular populations or samples, and sampling methods are usually carried out randomly.

This study's population consisted of all junior high school teachers from 7 (seven) junior high schools in the Air Kumbang District, for a total of 119 teachers. In this analysis, data was gathered by the use of a questionnaire.

\section{RESULTS AND DISCUSSION}

Table 1. Multicollinearity Test

\begin{tabular}{|c|c|c|c|}
\hline \multirow{2}{*}{\multicolumn{2}{|c|}{ Model }} & \multicolumn{2}{|c|}{ Collinearity Statistics } \\
\hline & & Tolerance & VIF \\
\hline \multirow[t]{4}{*}{1} & (Constant) & & \\
\hline & $\mathrm{X}_{1}$ (Motivation) & .906 & 1.103 \\
\hline & $\mathrm{X}_{2}$ (Discipline) & .7761 & 1.314 \\
\hline & $\mathrm{X}_{3}$ (Professionalism) & .708 & 1.412 \\
\hline
\end{tabular}

are greater than 0.10 and VIF values are less than 10.00 ,

In this study, the tolerance value for Motivation $\left(\mathrm{X}_{1}\right)$ was 0.906, Discipline tolerance $\left(\mathrm{X}_{2}\right)$ was 0.761, tolerance for Professionalism $\left(\mathrm{X}_{3}\right)$ was 0.708 . While the VFI value of Motivation (X1) is 1.103, the VIF value of Discipline $\left(\mathrm{X}_{2}\right)$ is 1.314 and the VIF value of Professionalism $\left(\mathrm{X}_{3}\right)$ is 1.412 . Since all tolerance values the data does not exhibit multicollinearity.

The coefficient of determination is used to assess the ability of all independent variables to describe variance in the dependent variable.

Table 2. Variables Correlation of Motivation

$\left(\mathbf{X}_{1}\right)$, Discipline $\left(\mathbf{X}_{2}\right)$, Professionalism $\left(\mathbf{X}_{3}\right)$ on Teacher Performance (Y)

\begin{tabular}{lcccc}
\hline Model & R & $\begin{array}{c}\text { R } \\
\text { Square }\end{array}$ & $\begin{array}{c}\text { Adjusted } \\
\text { R } \\
\text { Square }\end{array}$ & $\begin{array}{c}\text { Std. Error } \\
\text { of the } \\
\text { Estimate }\end{array}$ \\
\hline 1 & $.808^{\mathrm{a}}$ & 0.653 & 0.644 & 1.796 \\
\hline \multicolumn{4}{l}{$\begin{array}{l}\text { a. Predictors: (Constant), Motivation, Discipline, } \\
\text { Professionalism }\end{array}$}
\end{tabular}

In the Model Summary table above shows the magnitude of the correlation (R) of the motivation, discipline and professionalism variable on teacher performance of 0.808 , this shows a high correlation, and to find out how much influence it can be seen from the $\mathrm{R}$ Square value of 0.653 or $65.3 \%$ variable. Teacher performance can be explained or there is an influence with the motivation, discipline and professionalism variables, while the rest has an effect on other factors outside the research.

To find out the magnitude of the influence that occurs on the variables of motivation, discipline and professionalism on teacher performance simultaneously. Data processing was carried out to obtain multiple regression results as in the table: 
Table 3. Results of Mixed Regression Analysis

\begin{tabular}{|c|c|c|c|c|c|}
\hline \multirow[b]{2}{*}{ Model } & \multicolumn{2}{|c|}{$\begin{array}{r}\text { Unstandardized } \\
\text { Coefficients } \\
\text { Std. }\end{array}$} & $\begin{array}{l}\text { Standardized } \\
\text { Coefficients }\end{array}$ & \multirow[b]{2}{*}{$\mathrm{t}$} & \multirow[b]{2}{*}{ Sig. } \\
\hline & B & $\begin{array}{l}\text { Std. } \\
\text { Error }\end{array}$ & Beta & & \\
\hline $1 \quad$ (Constant) & 7.155 & 7.303 & & 0.980 & 0.329 \\
\hline Motivation & 0.486 & 0.050 & 0.561 & 9.721 & 0.000 \\
\hline Discipline & 0.430 & 0.075 & 0.362 & 5.747 & 0.000 \\
\hline Professionalism & 0.105 & 0.042 & 0.165 & 2.521 & 0.013 \\
\hline
\end{tabular}

a. Dependent Variable: Teacher Performance

The table above shows that the regression coefficient for the Motivation variable $\left(\mathrm{X}_{1}\right)$ is 0.486 , the Discipline variable $\left(\mathrm{X}_{2}\right)$ is 0.430 , the Professionalism variable $\left(\mathrm{X}_{3}\right)$ is 0.105 and produces a constant value of 7.155 resulting in the multiple regression equation for this study:

$$
\mathrm{Y}=7,155+0,468 \mathrm{X}_{1}+0,430 \mathrm{X}_{2}+0,105 \mathrm{X}_{3}+\mathrm{e}
$$

This means:

1. A constant of 7.155 is that if you ignore the motivation, discipline and professionalism variables, the teacher performance variable is 7.155.
2. The $X_{1}$ regression coefficient of 0.486 is that by keeping the Motivation score $\left(\mathrm{X}_{1}\right)$ constant, each addition of one unit of Motivation score $\left(\mathrm{X}_{1}\right)$ will increase the teacher's performance score by 0.486 .

3. The $\mathrm{X}_{2}$ regression coefficient of 0.430 is that by keeping the Discipline score $\left(\mathrm{X}_{2}\right)$ constant, each unit of discipline score $\left(\mathrm{X}_{2}\right)$ added will result in an increase the teacher's performance score by 0.430 .

4. The $\mathrm{X}_{3}$ regression coefficient of 0.105 is that by keeping the Professionalism score $\left(\mathrm{X}_{3}\right)$ constant, each addition of one unit of the Professionalism score $\left(\mathrm{X}_{3}\right)$ will increase the teacher's performance score by 0.105 .

Table 4. F-Test $X_{1}$ dan $X_{2}$ against $Y$

\begin{tabular}{|c|c|c|c|c|c|}
\hline Model & $\begin{array}{l}\text { Sum of } \\
\text { Squares }\end{array}$ & df & $\begin{array}{c}\text { Mean } \\
\text { Square }\end{array}$ & $\mathrm{F}$ & Sig. \\
\hline Regression & 676.243 & 2 & 338.121 & 100.247 & $.000^{\mathrm{b}}$ \\
\hline Residual & 391.253 & 116 & 3.373 & & \\
\hline Total & 1067.496 & 118 & & & \\
\hline
\end{tabular}

a. Dependent Variable: Teacher Performance

b. Predictors: (Constant), Motivation, Discipline

1. The F-test in table 4, the Motivation $\left(\mathrm{X}_{1}\right)$ and Discipline $\left(\mathrm{X}_{2}\right)$ variables together have an effect on Teacher Performance, this can be seen from the F- test value where the F-count value is 100.247 with a significance level of 0.00 smaller of $5 \%(\alpha=0.05)$, thus the motivation and discipline variables significantly influence teacher performance.

Table 5. F-Test $X_{1}$ dan $X_{3}$ against $Y$

\begin{tabular}{|c|c|c|c|c|c|}
\hline Model & $\begin{array}{l}\text { Sum of } \\
\text { Squares }\end{array}$ & df & $\begin{array}{c}\text { Mean } \\
\text { Square }\end{array}$ & $\mathrm{F}$ & Sig. \\
\hline Regression & 590.228 & 2 & 295.114 & 71.728 & $.000^{\mathrm{b}}$ \\
\hline Residual & 477.268 & 116 & 4.114 & & \\
\hline Total & 1067.496 & 118 & & & \\
\hline
\end{tabular}

a. Dependent Variable: Teacher Performance

b. Predictors: (Constant), Motivation, Professionalism

2. The F-test in table 5, the motivation variable $\left(\mathrm{X}_{1}\right)$, and professionalism $\left(\mathrm{X}_{3}\right)$ together have an effect on teacher performance, this can be seen from the F-test value where the F-count value is 71.728 with a significance level of 0.00 more. smaller than $5 \%(\alpha$ $=0.05)$, thus the motivation and professionalism variables significantly influence teacher performance. 
Table 6. F-Test $X_{2}$ dan $X_{3}$ against $Y$

\begin{tabular}{|c|c|c|c|c|c|c|}
\hline \multicolumn{2}{|c|}{ Model } & \multirow{2}{*}{$\begin{array}{c}\begin{array}{c}\text { Sum of } \\
\text { Squares }\end{array} \\
590.228\end{array}$} & \multirow{2}{*}{$\frac{\mathrm{df}}{2}$} & \multirow{2}{*}{$\begin{array}{c}\text { Mean } \\
\text { Square } \\
295.114\end{array}$} & \multirow{2}{*}{$\frac{F}{71.728}$} & \multirow{2}{*}{$\frac{\text { Sig. }}{.000^{\mathrm{b}}}$} \\
\hline 1 & Regression & & & & & \\
\hline & Residual & 477.268 & 116 & 4.114 & & \\
\hline & Total & 1067.496 & 118 & & & \\
\hline
\end{tabular}

a. Dependent Variable: Teacher Performance

b. Predictors: (Constant), Discipline, Professionalism

3. The F-Test in table 6 , the Discipline $\left(\mathrm{X}_{2}\right)$ and Professionalism $\left(\mathrm{X}_{3}\right)$ variables together have an effect on Teacher Performance, this can be seen from the F-test value where the F-count value is
33.665 with a significance level of 0.00 smaller of $5 \% \quad(\alpha=0.05)$, thus the discipline and professionalism variables significantly influence teacher performance.

Table 7. F-Test $X_{1}, X_{2}$ dan $X_{3}$ against $Y$

\begin{tabular}{|c|c|c|c|c|c|}
\hline Model & $\begin{array}{l}\text { Sum of } \\
\text { Squares }\end{array}$ & $\mathrm{df}$ & $\begin{array}{c}\text { Mean } \\
\text { Square }\end{array}$ & $\mathrm{F}$ & Sig. \\
\hline 1 Regression & 696.727 & 3 & 232.242 & 71.728 & $.000^{\mathrm{b}}$ \\
\hline Residual & 370.768 & 115 & 3.224 & & \\
\hline Total & 1067.496 & 118 & & & \\
\hline
\end{tabular}

a. Dependent Variable: Teacher Performance

b. Predictors: (Constant), Motivation, Discipline, Professionalism

4. The F-Test in table 7, the variable Motivation $\left(\mathrm{X}_{1}\right)$, Discipline $\left(\mathrm{X}_{2}\right)$ and Professionalism $\left(\mathrm{X}_{3}\right)$ together have an effect on Teacher Performance, this can be seen from the F-test value where the F-count value is 72.034 with a significance level 0.00 is smaller than $5 \%(\alpha=0.05)$, thus the motivation, discipline and professionalism variables significantly influence teacher performance.

\section{CONCLUSION}

Supported by the findings of the previous chapter's discussion, it can be concluded that the Motivation, Discipline and Professionalism variables, either individually, in pairs with 2 (two) variables (X) or together with 3 (three) variables (X) can significantly and significantly influence teacher performance variable (Y).

This demonstrates that attempts to increase teacher efficiency in Air Kumbang District junior high schools can be accomplished by rising encouragement., discipline and professionalism which in turn will increase teacher performance.

\section{ACKNOWLEDGMENT}

Our deepest gratitude goes to Dinas Pendidikan dan Kebudayaan Kabupaten Banyuasin, Chancellor of Palembang PGRI University, Director of the Postgraduate Program of PGRI Palembang University and the Education Management Study Program of PGRI Palembang University, who have supported us in doing this extraordinary thing. This project is funded independently. We also want to thank our Education Management friends who helped us a lot in a short time frame to complete this project.

\section{REFERENCES}

[1] Robbins SP, dan Judge. (2011). Perilaku Organisasi Buku 2, Jakarta: Salemba. Empat.

[2] Samsudin, S. (2012). Manajemen Sumber Daya Manusia. Bandung: Pustaka Setia.

[3] Uno, H. B. (2011). Teori Motivasi dan Pengukurannya. Jakarta: Bumi Aksara.

[4] Anoraga, P. (2006). Psikologi Kerja. Jakarta: PT. Rineka Cipta.

[5] Lian, B. (2020). Pengaruh Kepemimpinan Dan Motivasi Kerja Guru Terhadap Disiplin Kerja, Jurnal Manajemen, Kepemimpinan, dan Supervisi Pendidikan, Volume 6, No. 1.

[6] Aprida, Y., Fitria, H., \& Nurkhalis. (2020). Pengaruh Supervisi Kepala Sekolah dan Motivasi Kerja Guru terhadap Kinerja Guru. Journal of Education Research, 1(2), 160-164.

[7] Rivai, V., \& Sagala, E. J. (2011). Manajemen Sumber Daya Manusia Untuk Perusahaan: dari Teori Ke Praktik. Jakarta: Rajawali Pers.

[8] Umami., Lian, B., \& Missriani. (2021). Pengaruh Kepemimpinan dan Motivasi Kerja Guru terhadap Disiplin Kerja. JMKSP (Jurnal Manajemen, Kepemimpinan, dan Supervisi Pendidikan). Volume 6, No. 1, Hal. 52-66. 
[9] Davis, K. (2003). Organizational BehaviorHuman Behavior at Work 13thEdition. New Delhi: Mcgraw Hill Company.

[10] Hasibuan. (2014). Manajemen Sumber Daya Manusia. Jakarta: Bumi Aksara.

[11] Wirawan. (2015). Evaluasi Kinerja Sumber Daya Manusia (Teori, Aplikasi, Dan Penelitian). Jakarta: Salemba Empat.

[12] Rohani, I., Fitria, H., \& Rohana. (2020). Pengaruh Kepemimpinan Kepala Sekolah dan Disiplin Kerja Guru terhadap Kinerja Guru SDN di Kecamatan Sembawa. Jurnal Pendidikan Tambusai. Volume 4 Nomor 3. Hal.1883-1894.

[13] Ahmad, S., \& Hodsay, Z. (2020). Profesi Kependidikan dan Keguruan. Yogyakarta: Penerbit Deepublish.

[14] Fitria, H. (2018). The Influence of Organizational Culture and Trust Through The Teacher Performance In The Private Secondary School In Palembang. International Journal of Scientific 7 Technology Research. Volume 7.

[15] Ahmad, S. (2016). Ketahanmalangan Kepemimpinan Kepala Sekolah Salah Satu Faktor Penentu Keberhasilan Kepala Sekolah. Yogyakarta: Deepublish (Group Penerbitan CV. Budi Utama.

[16] Fattah, H., \& Wardarita, R. (2019). Kepuasan Kerja dan Kinerja Pegawai Budaya Organisasi, Perilaku Pemimpin, dan Efikasi Diri. Yogyakarta: Penerbit Elmatera.

[17] Hapizoh., Harapan, E., \& Destiniar. (2020). Pengaruh Profesionalisme Guru dan Supervisi Kepala Sekolah terhadap Kinerja Guru. JMKSP (Jurnal Manajemen, Kepemimpinan, dan Supervisi Pendidikan) Volume 5, No. 2.

[18] Brury, M. (2016). Pengaruh Kepemimpinan, Budaya Organisasi, Motivasi Kerja Dan Kepuasan Kerja Terhadap Kinerja Pegawai Pada Kantor SAR Sorong. Jurnal Riset Bisnis Dan Manajemen, Hal. $1-16$.

[19] Yamin, M., \& Maisah. (2010). Standarisasi Kinerja Guru. Jakarta: Gaung Persada.

[20] Barnawi., \& Arifin, M. (2014). Kinerja Guru Profesional: Instrumen Pembinaan Peningkatan dan penilaian. Yogyakarta: AR-RUZZ Media.

[21] Sugiono. (2013). Cara Mudah Menyusun Skripsi, Tesis \& Disertasi. Bandung: Alphabeta. 